\title{
Globalization of payment - Bitcoin ATMs at post offices
}

\author{
Juraj Fabus ${ }^{1, *}$, Viktoria Simkova ${ }^{1,}$ \\ ${ }^{1}$ University of Zilina, Faculty of Operation and Economics of Transport and Communications, \\ Univerzitna 1, 01026 Zilina, Slovakia
}

\begin{abstract}
Research background: As humanity evolves, so do the new payment options. Today, one of the most popular and powerful electronic money is Bitcoin. Over time, virtual currency is becoming one of the most widely available and used means of payment.

Purpose of the article: The aim of this paper is to analyse ATMs in post offices, focusing on virtual currency ATMs. The paper also includes an analysis of available ATMs for virtual currencies and a comparison of their capabilities.

Methods: We compare three most important ATM manufacturers and their most used models. It examines the use of those ATMs in post offices in Slovakia and abroad. Paper also analyses the attitude of customers of Slovak Post towards the deployment of virtual currency ATMs at its branches (on a sample of 400 respondents).

Findings \& Value added: In the Slovak Republic postal services are offered by several companies ( 19 out of 24 providers responded to our questionnaire). Slovak Post is leading provider of distribution, communication, and payment services in Slovakia. Czech Post is an example of country where virtual currency ATMs were introduced but subsequently withdrawn from post offices. In turn, Austrian Post Office is an example of a country where this system still operates and expands. While Slovak market still lacks such a service in the postal business, these trends will adapt over time. The virtual currency ATMs we have in Slovakia, are not operated by postal enterprises.
\end{abstract}

Keywords: bitcoin; ATM; post office

JEL Classification: $G 21 ; G 23 ; G 38$

\footnotetext{
* Corresponding author: juraj.fabus@,fpedas.uniza.sk
} 


\section{Introduction}

As humanity evolves, so do new payment options. From the earliest forms of money, through full-value and non-full-value money, we have come to today's electronic money (Kremenova and Gajdos, 2019). With the advent of modern technology, the way society handles and performs monetary transactions has changed tremendously (Kaur et al., 2018). In the global fnancial and business world, the wealth that an entity owns usually is composed of various assets or measured by different currencies, the value of which is dependent on the fluctuation of the foreign exchange rates. (Huand and Zhang, 2019). Bitcoin is one of the most popular and powerful electronic money today. Among all analyzed Bitcoin features, the extreme price volatility stands out most clearly compared to standard currencies (Ciaian et al., 2016). Roots of balance-of-payments crisis are found in the prevailing high degree of capital mobility and financial globalization (Calvo and Mendoza, 1996). The use of Automated Teller Machines has become increasingly popular throughout the world due to the widespread adoption of electronic financial transactions and better access to financial services in many countries (Ekinci et al., 2019).

The convergence of information and communication technologies is constantly creating new opportunities and digitizing state-owned enterprises in electronic services (Kvasnicova et al., 2016). This is also the case in the field of virtual currency, which at first had a very unfavourable history and people were sceptical about its future (Janoskova et al., 2021). Over time, virtual currency is becoming one of the most widely available and used means of payment. Many businesses are also following this trend, offering their customers the opportunity to buy and pay in this virtual currency for various services. Governments cannot discriminate between domestic and foreign creditors when enforcing debt payments. This creates novel interactions between domestic and international trade in assets (Broner and Ventura, 2011). Challenge from globalization is through global digital payments systems, which may compromise domestic policy sovereignty through effects on both monetary and financial stability (Obstfeld, 2021).

A number of companies offer postal services in the Slovak Republic, with Slovenská pošta, a.s., being the leading provider of distribution, communication and payment services on the market (Madlenak et al., 2021). Systems for the distribution of goods, both at the national and international level, are very important for the appropriate business functioning and also for a normal life of citizens (Lazarevic et al., 2020).

ATM - Automated Teller Machine - is a self-service device designed to dispense cash. The payment card and its associated PIN serve as a means of identification to enable cash withdrawals. The ATM dispenses paper money only. Fast payments are desirable in certain scenarios, for instance, when buying in vending machines, fast food restaurants, or withdrawing from an ATM (Perez-Sola et al., 2021). From the demand-side linkages, law modulates bank accounts and automated teller machine penetration (Asongu et al., 2021).

The first machine was installed during the Czechoslovak era (Janoskova et al., 2021). It was put into operation on 15 January 1989 in Prague on Wenceslas Square. It was installed by the Czech Savings Bank directly in the bank building. In the beginning, the machine was available only to employees.

The first bitcoin virtual currency machine in Europe was installed in ProgressBar on 21.11.2013. It was put into operation on 8.12.2013. The bitcoin virtual currency ATM works like a wallet. It converts euro banknotes into bitcoins according to the current exchange rate. This machine was manufactured by Lamassu. According to the problem of spliced money in ATM (Automatic Teller Machine), the paper puts forward a template matching algorithm for recognition of left and right numbers based on one-dimensional gray scale projection (Wang, 2021).

At the same time, the new era of information technology has also brought new elements to the means of exchange (Corejova et al., 2016). Virtual currency is an unregulated form of 
digital money and can be used as a means of payment. The central bank does not guarantee the stability of virtual currency, thus it is not controlled and guaranteed by the central bank. Virtual currencies exist only in the electronic world, in the form of social networks and online computer games. They are now increasingly used as a means of payment for services and goods at retailers. No or minimal transaction fees are incurred when making a payment. Bitcoin was the first currency to set conditions without a central P2P server, also referred to as crypto currency. Bitcoin is a decentralized virtual currency ("EBA warns consumer", 2013). Declining virtual currency issuance, like in Bitcoin, raises the price of virtual goods, which counteracts the traditional impact of a reduced inflation tax (Marchiori, 2021).

\section{Methodology}

The research addresses the issue of the use of ATMs for virtual currencies at post offices. We have chosen the Czech and Austrian post offices for comparison. We chose the Czech Post as an example of a country where these virtual currency ATMs were introduced but were subsequently withdrawn from post office branches. The Austrian Post Office, in turn, is an example of a country where this system is operating in several thousand post offices and is still expanding its portfolio.

The first ATM installed for virtual currency in the Czech Republic is in Holešovice, Prague. In the centre of the non-profit organisation Brmlab (iRozhlas, 2014).

Since 21 January 2015, it has been possible to purchase the virtual currency Bitcoin at branches of the Czech Post and Sazka terminals. It was operated by World BTC Business. Until then, virtual currency could only be physically purchased in self-service facilities in larger cities.

The procedure for buying Bitcoin started at easyconi.wbtcb.com, where the interested party chose the amount of Bitcoin they wanted, entered their Bitcoin wallet number, and then received an order confirmation with a payment identification number. Based on the identification number at the ČP, s.p. branch, the payment was made and then the purchased Bitcoins were transferred to the client's electronic wallet. The limit was from $500 \mathrm{Kč}$ to 25 000Kč (Denik.cz, 2015).

According to the Coin ATM radar, Austria ranks third with 138pcs of installed virtual currency ATMs. More than 1,800 post offices of the Austrian Post Office offer virtual currency sales. The service is provided by Bitpanda. Bitpanda was founded in Vienna in 2014. It has more than 300,000 users and plans to achieve the highest possible transaction volume (approx. $€ 200$ million), also thanks to the cooperation with the Austrian Post. The BitPanda platform (formerly Coinimal), is a digital currency purchasing service located in Austria and operating worldwide. It helps in the fast, secure and cheap purchase of several digital currencies using credit and debit cards or online bank transfer. It is also one of several services that sell physically redeemed crypto vouchers.

The easiest way to purchase virtual currency is by using an automated teller machine (ATM). There are two basic types of machines One-Way (one-way) and Two-Way (twoway). One-Way machines only offer a deposit option. Two-Way machine offers deposit and withdrawal.

There are 31 companies that manufacture virtual currency machines. We will review the most well-known ones on the market (according to the website coinatmradar.com) ("Coin ATM radar", n.d.). The ATMs are Genesis Coin, General Bytes, Lamassu and Bitaccess. In this section we will compare the top 3 ATM manufacturers and their most used models. GENESIS with 937 installed ATMs, GENERAL BYTES with 794 installed ATMs and LAMASSU with 326 installed ATMs out of a total of 2844 installed ATMs.

The research mainly included a survey on the use of ATMs in post offices with a focus on virtual currency. We chose the research method in the form of questionnaires. The main 
objective of the questionnaires was to find out the knowledge of digital currencies among customers (questionnaire 1) and in postal businesses (questionnaire 2). The questionnaires were developed on the Google web portal, using the Google Forms application. The questionnaires were sent via social network and email. For Questionnaire 2, we contacted the businesses by telephone, email and additionally completed the questionnaire on their behalf.

We divided our work into two phases. The first phase is a preparatory phase where we set out the research questions to be investigated. The second phase is the implementation phase where we answered the set research questions. For the sample size calculation, the $95 \%$ confidence level of the estimation, and a maximum margin of error of $\pm 10 \%$ was set. The proportion of the trait is 0.5 . The minimum sample size for respondents of customers of the Slovak Post is $\mathbf{3 8 4}$ respondents. The research included 12 research assumptions. For the calculation of the sample of postal enterprises, which is 24 , the $95 \%$ confidence level of the estimation, the maximum allowable margin of error $\pm 5 \%$ and the sign proportion 0.5 were set. The minimum sample size in this case is $\mathbf{1 9}$ respondents. The research included 4 research assumptions.

\section{Results and Discussion}

At the beginning of 2021, there were 9 two-way (deposit and withdrawal) and 8 one-way (deposit only) virtual currency machines in Slovakia (Kryptomena, 2014). Slovenská pošta a.s., does not yet offer and does not use this service (ATMs for virtual currencies).

The Slovak Republic is among the leaders in the number of installed virtual currency machines, although the number of ATMs is not large. It is one of the first countries where such a virtual currency ATM has been installed. Specifically, according to Coin ATM Radar, the Slovak Republic is in thirteenth place with 17 virtual currency machines installed. The Czech Republic, according to Coin ATM Radar, is in sixth place with 40pc of installed virtual currency ATMs.

The following is a graphical display of the latest information on ATMs installed around the world. Figure 1. shows all installed bitcoin ATMs, by specific manufacturer.

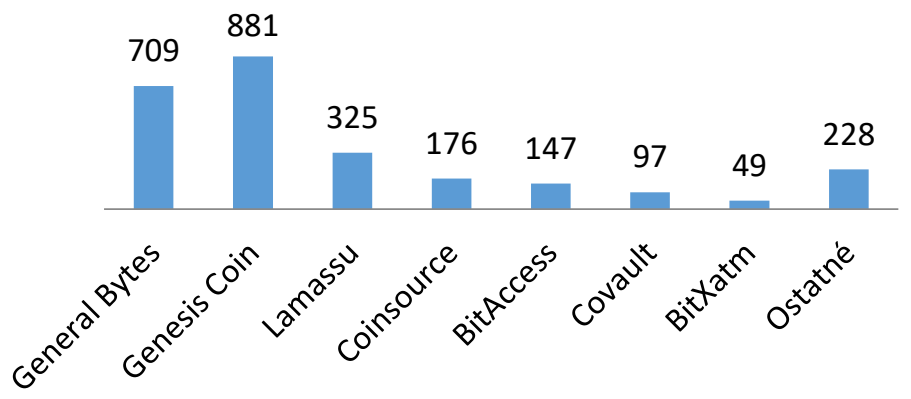

Figure 1: Graphical representation of ATM share by manufacturer (Own elaboration)

Figure 2. shows how many Bitcoin ATMs, are installed in all continents. (The remaining 3 continents are not included in the graph, due to unpublished information on the number of virtual currency ATMs). 


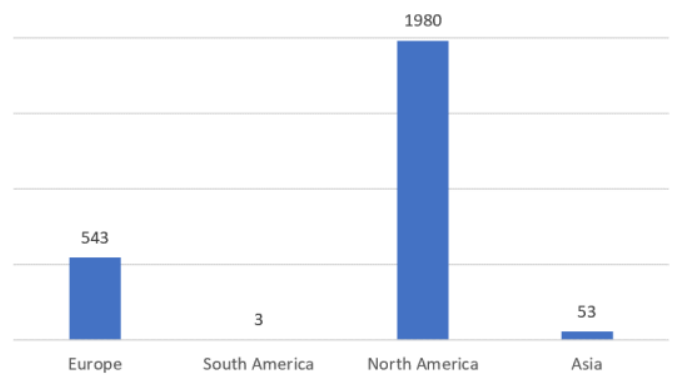

Figure 2: Graphical representation of ATM share by continent (Own elaboration)

Figure 3. shows how many of the total number of installed ATMs, One-Way (one-way) and Two-Way (two-way) machines.

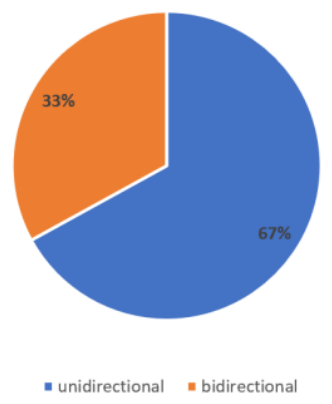

Figure 3. Graphical representation of unidirectional and bidirectional ATM (Own processing)

In Table, the three most commonly used virtual currency ATMs are compared for the example. The first column divides the ATMs according to deposit and withdrawal capabilities, the second row lists the ATM's banknote capacities. The third row compares the basic merits of ATMs. The fourth row describes the mounting option of the ATM itself. The last row lists the prices of ATMs.

Table: Comparison of ATM functions for virtual currency

\begin{tabular}{|c|c|c|}
\hline $\begin{array}{c}\text { GENESIS } \\
\text { GENESIS 1 }\end{array}$ & $\begin{array}{c}\text { GENERAL BYTES } \\
\text { BATMTWO } \\
\text { CLASSIC }\end{array}$ & $\begin{array}{c}\text { LAMASSU DOURO } \\
\text { +SANTO TIRSO }\end{array}$ \\
\hline $\begin{array}{c}\text { unidirectional/ } \\
\text { bidirectional }\end{array}$ & unidirectional & $\begin{array}{c}\text { unidirectional/ } \\
\text { bidirectional }\end{array}$ \\
\hline $\begin{array}{c}\text { Capacity } 2200 \mathrm{pcs} \\
\text { banknotes and 1700- } \\
6800 \text { pcs output. }\end{array}$ & $\begin{array}{c}\text { Capacity } 600 \mathrm{pcs} \\
\text { banknotes and } 2 \text { x500 } \\
\text { pcs output. }\end{array}$ & $\begin{array}{c}\text { Capacity } 600 \mathrm{pcs} \\
\text { banknotes and 2 x500 } \\
\text { pcs output. }\end{array}$ \\
\hline $\begin{array}{c}\text { EMV card reader, } \\
\text { validator, thermal } \\
\text { printer, camera, } \\
\text { barcode reader, } \\
\text { electronic cash } \\
\text { register, barcode } \\
\text { scanner. }\end{array}$ & $\begin{array}{c}\text { Electronic printer, } \\
\text { validator, FHD touch } \\
\text { screen with android, } \\
\text { electronic cash register. }\end{array}$ & $\begin{array}{c}\text { QR reader, lockable } \\
\text { vault, validator, all } \\
\text { currencies supported, } \\
\text { database of third-party } \\
\text { services. }\end{array}$ \\
\hline \multicolumn{2}{|c}{} & \multicolumn{2}{|c|}{} \\
\hline
\end{tabular}




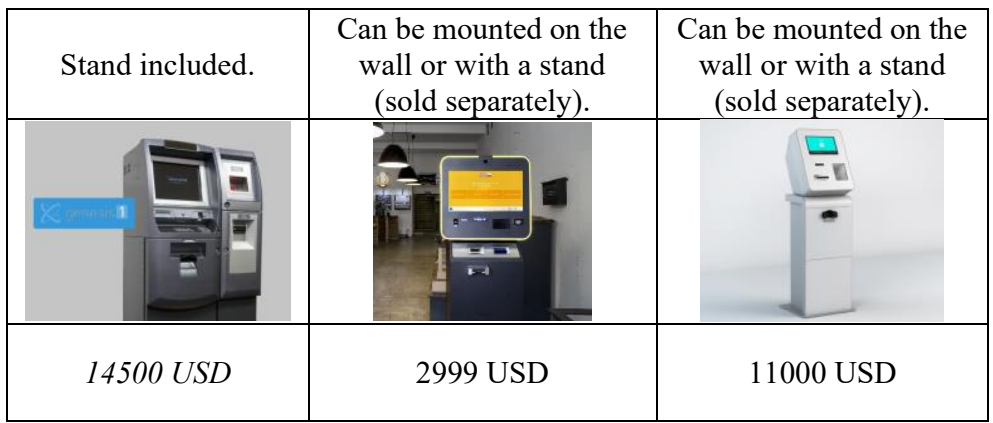

Source: Own elaboration, 2021

The following is a selection of a few findings from the questionnaire. One of the questions was: "Is there a virtual currency ATM in your city?"

With this question, we wanted to find out if there is a virtual currency ATM in the respondent's neighbourhood. The highest number of respondents $162(55 \%)$ answered that there is no virtual currency ATM in their area, $108(37 \%)$ respondents do not know if there is a virtual currency ATM in their area. And only $24(8 \%)$ respondents answered that there is a virtual currency ATM in their area. The research hypothesis was half of the respondents do not know if there is a virtual currency ATM in their neighborhood. This assumption was not confirmed (Figure 4). The majority of respondents $(55 \%)$ answered that there is no virtual currency ATM in their area.

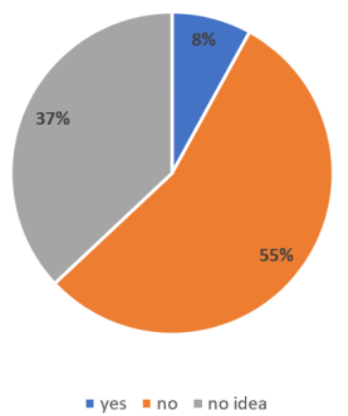

Figure 4. Graphical representation of an ATM in the vicinity (Own processing)

When asked (Figure 5) if they would like to see virtual currency ATMs at post offices, the majority of the respondents said they did not know 96 (33\%). Conversely, 60 (21\%) respondents would welcome this option. Rather yes 54 (18\%), rather no $42(14 \%)$ and no 42 (14\%). Research Premise: Virtual ATMs would be welcomed by half of the respondents in the postal enterprise. This assumption was confirmed, with most respondents interested in a virtual currency ATM. 


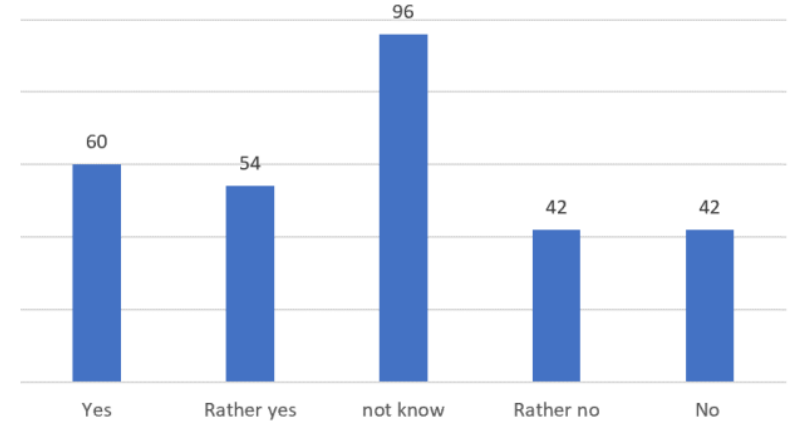

Figure 5. Interest in ATM in a postal company (Own elaboration)

The next question (Figure 6) - Would you take advantage of the Postal Service's virtual currency payment option? This question is closely related to the previous one, as indicated by the responses that the majority of the respondents surveyed would not know if they would use this service $78(26 \%), 77(26 \%)$ indicated no, $53(18 \%)$ indicated rather no, $34(12 \%)$ said yes, and $52(18 \%)$ of the respondents surveyed said rather yes. Research Premise: Half of the respondents would use the option of paying with digital currency at a postal business. This assumption is incorrect, with most respondents answering that they did not know if they would use this service.

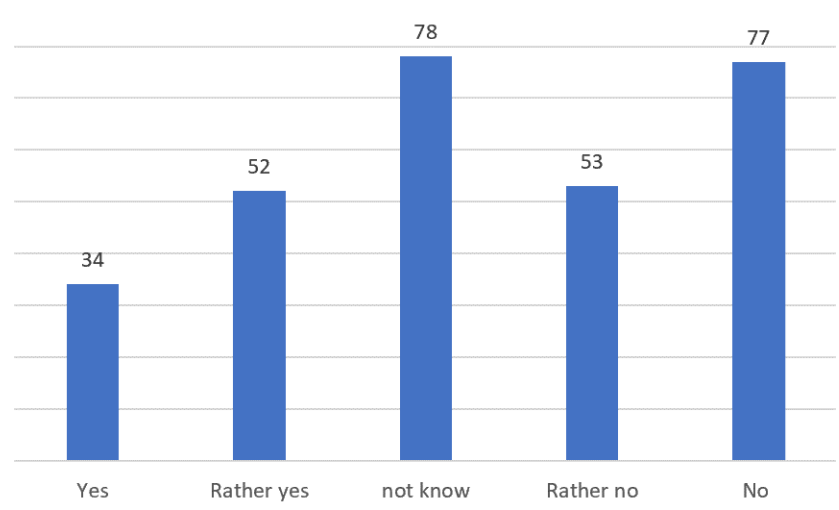

Figure 6: Interest in paying for postal services in virtual currency (Own elaboration)

The second questionnaire surveyed postal businesses. When asked whether they offer the possibility to pay with virtual currency, all postal businesses surveyed gave the same answer that they do not offer this service. Research premise: No postal business offers the possibility to pay with digital currency. This assumption was confirmed; no postal business in the Slovak Republic offers this service.

We also asked: Do you plan to offer the possibility to pay with digital currency in your postal company in the future? The question focused on whether they plan to offer the possibility to pay with digital currency in the postal undertaking. Most businesses $13(68 \%)$ answered no, with the remaining 6 businesses unable to answer. Research Premise: No postal businesses plan to introduce the ability to pay with virtual currency. This assumption was also found to be true (Figure 7); no postal enterprise plans to introduce digital currency payments. 


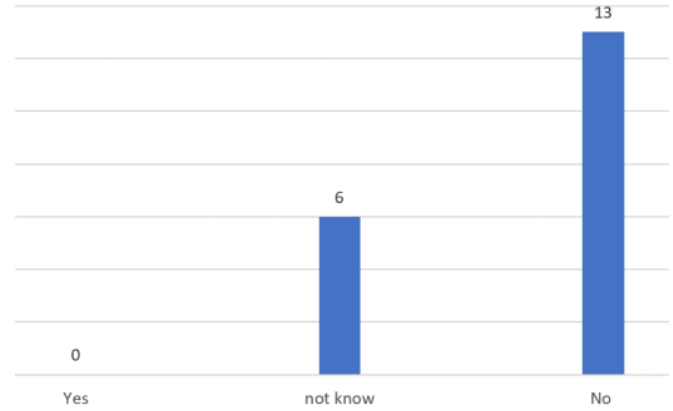

Figure 7: Possibility to pay for postal services in virtual currency (Own elaboration)

Further research showed that if customers were interested in paying with digital currency, 4 postal businesses would be interested in operating ATMs. If there was real interest in this service $4(21 \%)$ postal businesses could imagine offering this service. 11 (58\%) postal businesses could not answer, and $4(21 \%)$ businesses indicated a no answer.

\section{Conclusion}

Strong competition is forcing businesses to constantly expand and digitise their portfolio to stay in business. While our market does not yet have a digital currency purchasing service through virtual currency ATMs in the postal enterprise, these trends will adapt over time. The virtual currency ATMs we have in Slovakia are not operated by postal enterprises.

Europe is currently a relatively small virtual currency exchange market. Compared to other major markets such as the US, Japan and China, bitcoin ATMs are lacking in Europe. Other countries, such as South Korea, have switched to ATM purchases due to low operating and production costs. Applications based on the bitcoin currency have started to work with banks and ATM service providers to enable bitcoin purchases at existing ATMs.

Using questionnaires, we conducted a survey on the real interest of postal customers. The responses show that no postal enterprise offers this service. The demand for the service has not been observed by postal businesses to the extent that they would consider introducing such machines or selling virtual currency themselves. However, they can imagine, in case of real interest from customers, offering this service.

\section{Acknowledgements}

The Paper is published with the support of project VEGA 1/518/19. This research has been further supported by the University of Zilina in the scope of Institutional research 1/KS/2020, by Project K-21-015-00 and Project CIS by Ministry of Educations SR.

\section{References}

1. Asongu, S. A., Agyemang-Mintah, P., \& Nting, R. T. (2021). Law, mobile money drivers and mobile money innovations in developing countries. Technological Forecasting and Social Change, 168, Article120776.

2. Broner, F., \& Ventura, J. (2011). Globalization and Risk Sharing. The Review of Economic Studies, 78(1), 49-82.

3. Calvo, G. A., \& Mendoza, E. G. (1996). Mexico's balance-of-payments crisis: a chronicle of a death foretold. Journal of International Economics, 41(3-4), 235-264. 
4. Ciaian, P., Rajcaniova, M., \& Kancs, D. (2016). The digital agenda of virtual currencies: Can BitCoin become a global currency? Information Systems and E-Business Management, 14(4), 883-919.

5. Coin ATM radar (2021). Bitcoin ATM Map. https://coinatmradar.com/

6. Corejova T., Rovnanova A., Genzorova T., \& Valica M. (2016). Digital transformation and its impact on brand. Marketing Identity, 4(1/1) (pp. 54-65).

7. Denik.cz (2015, January 21). Bitcoinom sa dá platit' aj na CZ poštách. https://www.denik.cz/ekonomika/za-bitcoiny-je-mozne-platit-na-postach-aterminalech-sazky-20150121.html/

8. Dobroselskyi, M., Madleňák, R., \& Laitkep, D.: Analysis of return logistics in ecommerce companies on the example of the Slovak Republic. Transportation Research Procedia, 55, 318-325.

9. EBA (2013, December 12). EBA warns consumers on virtual currencies. https://www.eba.europa.eu/eba-warns-consumers-on-virtual-currencies

10. Ekinci, Y., Serban, N., \& Duman, E. (2019). Optimal ATM replenishment policies under demand uncertainty. Operational Research, 21(2), 999-1029.

11. Huang, H., \& Zhang, Z. (2019). Virtual Standard Currency for Approximating Foreign Exchange Rates. International Journal of Electronic Commerce, 23(1), 33-62.

12. iRozhlas (2014, March 1). V pražských Holešovicích funguje bankomat na bitcoiny. Prvni v Česku. https://www.irozhlas.cz/node/5915425/

13. Janoskova P., Kovacikova M., \& Stofkova, K. R. (2021). Mobile applications for education used during the pandemic of Covid 19. 13th International Conference on Education and New Learning Technologies, EDULEARN21, 1 (pp. 9585-9594).

14. Janoskova P., Stofkova K. R., Kovacikova M., Stofkova J., \& Kovacikova K. (2021). The Concept of a Smart City Communication in the Form of an Urban Mobile Application. Sustainability, 13(17), Article 9703.

15. Kaur, P., Krishan, K., Sharma, S. K., \& Kanchan, T. (2018). ATM Card Cloning and Ethical Considerations. Science and Engineering Ethics, 25(5), 1311-1320.

16. Kremenova, I., \& Gajdos, M. (2019). Decentralized networks: The future internet. Mobile Networks and Applications, 24(6), 2016-2023.

17. Kryptomena (2014, January 23). Prvý obojsmerný bankomat v Európe. http://www.kryptomena.sk/2014/01/23/prvy-obojsmerny-bankomat-v-europe-bude-asiv-prahe/

18. Kvasnicova, T., Kremenova, I., Fabus, J., \& Babusiak, B. (2016). E-commerce user experience: do we feel under pressure during online shopping. Proceedings of the 20th World Multi-Conference on Systemics, Cybernetics and Informatics (pp. 41-44). WMSCI.

19. Lazarević, D., Dobrodolac, M., ŠVadlenka, L., \& Stanivuković, B. (2020). A MODEL FOR BUSINESS PERFORMANCE IMPROVEMENT: A CASE OF THE POSTAL COMPANY. Journal of Business Economics and Management, 21(2), 564-592.

20. Marchiori, L. (2021). Monetary theory reversed: Virtual currency issuance and the inflation tax. Journal of International Money and Finance, 117, Article 102441.

21. Obstfeld, M. (2021). Reprint: Two challenges from globalization. Journal of International Money and Finance, 114, Article 102408.

22. Pérez-Solà, C., Delgado-Segura, S., Navarro-Arribas, G., \& Herrera-Joancomartí, J. (2018). Double-spending prevention for Bitcoin zero-confirmation transactions. International Journal of Information Security, 18(4), 451-463.

23. Stofkova, Z.; Soltes, V.; \& Stofkova, J. (2019). Survey of the citizens digital skills in the region. 12th International conference of education, research and innovation, ICERI Proceedings (pp. 7127-7132), IATED Academy. 
24. Wang, Z. (2021). An algorithm for ATM recognition of spliced money based on image features. Multimedia Tools and Applications, 80(8), 11471-11489. 